\title{
Susceptibility of Nectomys rattus (Pelzen, 1883) to Experimental Infection with Schistosoma mansoni (Sambon, 1907): a Potential Reservoir in Brazil
}

\author{
Ana Cláudia Ribeiro ${ }^{+}$, Arnaldo Maldonado Jr., Paulo Sergio D'Andrea, \\ Giovane Oliveira Vieira, Luís Rey
}

Laboratório de Biologia e Controle da Esquistossomose, Departamento de Medicina Tropical, Instituto Oswaldo Cruz, Av. Brasil 4365, 21045-900 Rio de Janeiro, RJ, Brasil

The aim of the present research was to evaluate the potential of Nectomys rattus, the "water rat", to develop Schistosoma mansoni infection. Comparison with N. squamipes was carried out. Both species of rodents were submitted to transcutaneous infection using different infective cercariae loads: 50, 100 or 500. N. rattus showed high susceptibility to S. mansoni, with an infection rate of $71 \%$. Rodents were able to excrete viable eggs of S. mansoni in the feaces during all infection period. For both species, the small intestine, followed by the liver and the large intestine, presented the highest concentration of eggs among the surveyed organs. Infection caused no animal death. Moreover, N. rattus accomplished the parasite's life cycle, by infecting the snails Biomphalaria glabrata and later Mus musculus. These evidences indicate that both $\mathrm{N}$. rattus, as for $\mathrm{N}$. squamipes are potential reservoirs for schistosomiasis in Brazil. Considering the fact that $\mathrm{N}$. rattus and $\mathrm{N}$. squamipes exist in the same natural ecosystems of $\mathrm{S}$. mansoni, we suggest that these rodents must be regarded as influential factors in epidemiology surveys.

Key words: Nectomys rattus - Nectomys squamipes - wild rodent - Schistosoma mansoni - experimental infection

The occurrence of wild populations of small rodent naturally infected in endemic schistosomiasis areas had been considered as an additional complication factor for the control of the disease (Rey 1993).

The species Nectomys squamipes, the "water rat", is one of the most important non-human hosts for Schistosoma mansoni in Brazil (Antunes et al. 1973, Picot 1992). This species excretes viable eggs of the parasite during its hole life-span (RodriguesSilva 1988) and shows strong fitness to parasitism (Machado-Silva et al. 1994). Furthermore, $N$. squamipes has a high susceptibility to experimental infection (Souza et al. 1992), reinfection (Maldonado Jr. et al. 1994), and with a moderate pathogenic response (Silva \& Andrade 1989).

Recent taxonomic revision of Nectomys genus (Bonvicino 1994) resulted in a new designation for last named $N$. squamipes found in the ParanáParaguai basin, Amazônia basin and small basins

\footnotetext{
This research was supported by Papes/Fiocruz and CNPq.

${ }^{+}$Corresponding author. Fax: +55-21-280.3740. E-mail: acrsilva@gene.dbbm.fiocruz.br

Received 4 May 1998

Accepted 31 August 1998
}

at the eastern Brazilian coast, from north of the municipality of São Lourenço da Mata (State of Pernambuco) to the Amazon river. That new given designation is $N$. rattus $(2 \mathrm{n}=52)$.

$N$. squamipes $(2 \mathrm{n}=56)$ distribution has been restricted to the Atlantic coast of Brazil, in the basins of São Francisco river and Paraná river, as well as in the small independent basins of southern São Lourenço da Mata, in eastern Brazil.

The broad distribution of $N$. rattus includes endemic areas of schistosomiasis apart from those where $N$. squamipes are found. However, there have been only two reports where $N$. rattus (formerly named $N$. squamipes amazonicus) were found naturally infected (Bastos et al. 1982, 1984).

The aim of this research was to evaluate the potential of $N$. rattus to develop S. mansoni infection, and its ability to complete the parasite's life cycle under experimental conditions. All results were compared to the $N$. squamipes relation with $S$. mansoni infection.

\section{MATERIALS AND METHODS}

Experimental groups - Thirty seven specimens of $N$. rattus and 58 specimens of $N$. squamipes of both sexes, aged 3 to 5 months and weighing 250 to $300 \mathrm{~g}$ were used. All experimental animals were raised in our laboratory colonies (D'Andrea et al. 1996). The colony of the N. rattus derived from animals captured in the State of Goiás 
(Central Brazil) and the $N$. squamipes derived from animals captured in the State Rio de Janeiro (southeastern Brazil). Mus musculus Swiss Webster were used to test $S$. mansoni cercariae infective after $N$. rattus and Biomphalaria glabrata passage.

The rodents were allocated in six experimental subgroups according to cercariae loads used (50, 100 or 500$)$ : R-50 $(\mathrm{n}=12), \mathrm{R}-100(\mathrm{n}=10)$ and $\mathrm{R}-$ $500(\mathrm{n}=9)$ for $N$. rattus and $\mathrm{S}-50(\mathrm{n}=24), \mathrm{S}-100$ $(\mathrm{n}=11)$ and $\mathrm{S}-500(\mathrm{n}=17)$ for $N$. squamipes.

Experimental infection - The animals were exposed to transcutaneous infection through their tails during thirty minutes. S. mansoni cercariae used in this study belonged to the Belo Horizonte (BH) strain maintained in B. glabrata snails and Swiss Webster mice (Paraense \& Corrêa 1989).

After 16 weeks of infection, the rodents were sacrificed and submitted to portal-hepatic perfusion by Pellegrino and Siqueira (1956) technique, followed by a collection of worms from mesenteric veins with a pointed tool.

Coprologic examinations - Examinations were carried out daily by the Kato-Katz technique (Katz et al. 1972), from the 35th to the 48th day, in order to define the pre-patent period. In the next step, examination was carried out twice a week until the 16 th week of infection (two slides per sample). The total amount of eggs excreted in the feaces was compared among the subgroups. Five especimens of B. glabrata were exposed to all miracidia hatched from $1.5 \mathrm{~g}$ of feaces per rodent from the subgroups R-500 and S-500, totaling 30 snails per subgroup. Cercariae released were tested for its infecting capacity for M. musculus (50 larvae per animal).

Counting of eggs lodged in the different organs - The lungs, spleen, liver, small and large intestines were weighted prior to digestion in a 4\% aqueous $\mathrm{KOH}$ solution (Cheever 1968) and the number of eggs were estimated per gram of tissue.

Quantitative oogram - The small intestine were removed from the pyloric sphincter to the ileo-cecal valve and divided into three equal sections, where samples of $1 \mathrm{~cm}$ length were taken for an oogram performance (Pellegrino \& Faria 1965)

Statistical analysis - Data obtained were analyzed by the Kruskal-Wallis and/or Mann-Withney tests. Differences in sex-ratio of recovered worms were tested using chi-square test. The relationship between the total number of eggs obtained from the oogram performance and the number of recovered couple worms was tested by the Spearman's correlation coefficient. Values of $p<0.05$ were considered statistically significant (Siegel 1975).

\section{RESULTS}

Cercariae penetration sucess was greater than $90 \%$ in all experimental subgroups. Regardless of the cercariae loads used, infection rates were $71 \%$ and $80 \%$ for $N$. rattus and $N$. squamipes, respectively. Independent analysis by subgroups revealed higher susceptibility for R-500 and S-500 with infection rates of $100 \%$ and $94 \%$, respectively. All subgroups always presented more than $70 \%$ except for R-100, which presented an infection rate of $50 \%$, and what is significantly different from other subgroups $(\mathrm{p}<0.05)$.

Regarding the amount of worms recovered, subgroup R-50 showed a significant greater number than subgroup S-50 ( $<<0.01)$, (Figure). There was no difference in the number of worms recovered between the subgroups exposured to 50 and 100 cercariae loads for a single species. However, it was observed a significant difference among the subgroups exposed to loads of 50 and 100 cercariae, and the subgroup exposed to 500 cercariae when both species were compared. In all of the subgroups the sex-ratio was biased to male: $2.5: 1$ (R-50); 5.0:1 (R-100); 4.6:1 (R-500); 3.4:1 (S-50); 3.3:1 (S-100) and 2.6:1 (S-500) $(0.001<\mathrm{p}<0.01$ for all subgroups).

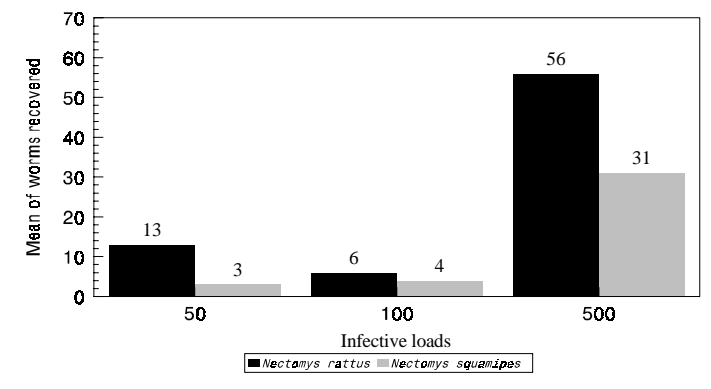

Total of worms recovered in Nectomys rattus and $N$. squamipes experimentally infected with different infective loads of Schistosoma mansoni.

The pre-patent period varied from 40 to 42 days to both Nectomys species in all experimental subgroups.

The amount of $S$. mansoni's eggs excreted in the feaces of Nectomys varied greatly among individuals of the same experimental subgroup, and for the same individual throughout the infection period. Values varied from 0 to 264 eggs per gram of feaces, characterizing an assyncronic egg excretion pattern for either Nectomys species. Despite this variation, viable eggs were observed during the hole period of observation in all subgroups.

B. glabrata snails were successfully infected by miracidia from eggs from feaces of both sub- 
groups (R-500 and S-500). These snails released cercariae which were infective to $M$. musculus. Adult worms of both sexes were recovered from those animals at nine week after infection.

The amount of eggs found in different organs after $\mathrm{KOH}$ digestion and in the quantitative oogram revealed a greater number for $N$. rattus than for $N$. squamipes (Table I). However a significant difference was observed only at the 50 cercariae subgroup $(\mathrm{p}<0.05)$.

\section{TABLE I}

Comparison among the total amount of eggs of Schistosoma mansoni placed on tissues by digestion by $\mathrm{KOH}$ and oogram methods of Nectomys rattus and $N$. squamipes (Mean values \pm Standard Desviation)

\begin{tabular}{lrr}
\hline Subgroup & \multicolumn{1}{c}{$\begin{array}{c}\text { Eggs found in tissues } \\
\text { Quantitative oogram }\end{array}$} \\
\hline R-50 & \multicolumn{2}{c}{ Digestion } \\
S-50 & $261 \pm \pm 182.3$ & $14977 \pm 4079.3$ \\
R-100 & $370 \pm 161.9$ & $5664 \pm 1302.0$ \\
S-100 & $257 \pm 123.7$ & $8801 \pm 379 \pm 3056.2$ \\
R-500 & $1386 \pm 365.7$ & $83684 \pm 3665.8$ \\
S-500 & $878 \pm 257.3$ & $74467 \pm 13013$ \\
\hline
\end{tabular}

R-50: $N$. rattus exposed to 50 cercariae; R-100: $N$. rattus exposed to 100 cercariae; R-500: $N$. rattus exposed to 500 cercariae; S-50: N. squamipes exposed to 50 cercariae; S-100: N. squamipes exposed to 100 cercariae; S-500: N. squamipes exposed to 500 cercariae.
Through tissue digestion it was possible to determine that the greater number of eggs were placed in the small intestine, followed by the liver and the large intestine. Few eggs were found in the lungs and spleen (Table II). These results were common to both species.

Egg's distribution along the segments of the small intestine had similar amounts for $N$. rattus and $N$. squamipes. For both species, $90 \%$ of eggs were found in the small intestine, and a small number of eggs in the large intestine (Table III). There was no significant difference in eggs distribution among intestines in both species.

There was a positive correlation between the number of eggs found in the intestine and the number of couple worms recovered $(p<0.02)$ in the different subgroups of both species.

\section{DISCUSSION}

Although $S$. mansoni shows a low specificity in relation to its vertebrate host choice (Combes 1990), only few species, including rodents, are capable of developing the infection and allowing the parasite to complete its biological cycle in natural environment (Rey 1993).

The rodent $N$. rattus is the second most widely distributed Nectomys species over the Brazilian schistosomiasis endemic area. Despite of that, there is no data concerning its potential to act as a reservoir.

\section{TABLE II}

Mean number of eggs of Schistosoma mansoni found in one gram of tissue in the analyzed organs of Nectomys rattus (R) and $N$. squamipes (S), after $\mathrm{KOH}$ digestion. The results presented the variance values (SD)

\begin{tabular}{lccccc}
\hline Subgroups & Lungs & Spleen & Large intestine & Liver & Small intestine \\
\hline R-50 & 0 & 0 & $4.1 \pm 2.7$ & $20.3 \pm 8.7$ & $75.6 \pm 12.4$ \\
S-50 & 0 & $5.9 \pm 2.9$ & $2.2 \pm 1.5$ & $35.9 \pm 9.9$ & $56.0 \pm 10.1$ \\
R-100 & 0 & 0 & $9.7 \pm 4.5$ & $26.2 \pm 7.8$ & $63.1 \pm 13.2$ \\
S-100 & $1.0 \pm 0.2$ & 0 & $7.3 \pm 3.5$ & $19.8 \pm 5.5$ & $71.9 \pm 10.9$ \\
R-500 & 0 & 0 & $15.8 \pm 6.8$ & $16.2 \pm 7.3$ & $68.0 \pm 20.1$ \\
S-500 & 0 & $3.0 \pm 1.8$ & $10.0 \pm 3.9$ & $23.7 \pm 9.8$ & $59.2 \pm 17.4$ \\
\hline
\end{tabular}

TABLE III

Quantification of the number of eggs (oogram) in percentage and variance values (SD) on the proximal, medial and distal sections of small intestine, as well as large intestine of Nectomys rattus (R) and N. squamipes (S) infected with 50, 100 or 500 cercariae of Schistosoma mansoni

\begin{tabular}{lcccc}
\hline & $\begin{array}{c}\text { Small intestine } \\
\text { (Proximal) }\end{array}$ & $\begin{array}{c}\text { Small intestine } \\
\text { (Medial) }\end{array}$ & $\begin{array}{c}\text { Small intestine } \\
\text { (Distal) }\end{array}$ & Large intestine \\
\hline R-50 & $38.9 \pm 13.7$ & $29.4 \pm 14.4$ & $25.7 \pm 9.8$ & $6.0 \pm 2.3$ \\
S-50 & $27.9 \pm 10.8$ & $31.9 \pm 12.4$ & $38.0 \pm 17.0$ & $2.2 \pm 0.7$ \\
R-100 & $29.6 \pm 11.2$ & $38.0 \pm 19.9$ & $27.1 \pm 10.2$ & $5.3 \pm 2.1$ \\
S-100 & $24.6 \pm 9.3$ & $37.0 \pm 19.5$ & $36.7 \pm 15.8$ & $1.7 \pm 0.9$ \\
R-500 & $38.0 \pm 17.9$ & $36.3 \pm 15.8$ & $20.6 \pm 8.8$ & $5.1 \pm 2.0$ \\
S-500 & $28.7 \pm 9.8$ & $34.5 \pm 13.2$ & $30.6 \pm 11.7$ & $6.2 \pm 2.3$ \\
\hline
\end{tabular}


$N$. rattus revealed high experimental infection rates, presenting similar levels of susceptibility compared to N. squamipes (Maldonado et al. 1993). Also, both species presented similar results for the pre-patent period and the number of recovered worms in equivalent experimental groups.

Despite a larger number of recovered worms in the $N$. rattus subgroup (R-50), both species presented similar responses to infection by S. mansoni, when exposed to the same number of cercariae.

The sex-ratio biased to male found in this study is in agreement with the results of natural infection in $N$. squamipes observed by Rodrigues-Silva et al. (1992). On the other hand, Souza et al. (1992) verified that in a long-term infection period (between 12th and 16th post infection) there is a decrease toward females worms. However, these results differed from those found by Maldonado Jr. et al. (1994) for $N$. squamipes under experimental conditions, where the sex ratio was well-balanced. Moné (1997) pointed out that sex-ratio among adult worms from vertebrate hosts are usually male-biased. However, the working mechanisms for the existing gap between male and female still requires a better explanation.

The great variation in the number of excreted eggs observed in this study was similar to results found in naturally infected $N$. squamipes (Carvalho 1982), Holochilus brasiliensis leucogaster (Dias et al. 1978) and in wild African rodents (Sène et al. 1996).

In both, tissue digestion and quantitative oogram, coincident results were found in regard to the predominance of eggs in the small intestine. However, these results differed from those demonstrated by Rodrigues-Silva (1988) for $N$. squamipes, where no significant difference among segments of the intestines were found. Yet, the studies by Imbert-Establet et al. (1997), analyzing two African wild rodents infected with $S$. intercalatum, verified that eggs concentrate mainly in the small intestine of Mastomys huberti. As for Arvicanthis niloticus, eggs distribution changes with the development of the infection, when eggs start to concentrate in the large intestine.

The positive correlation found between the number of eggs in the intestines and the number of couple worms, in both species, revealed that there was not fecundity down regulation dependent of the parasite load in S. mansoni-Nectomys model. Also, Coyne and Smith (1991) observed similar results for $S$. matthei.

Based on the results of this study and considering the fact that $N$. squamipes and $N$. rattus have semi-aquatic habits (Ernest \& Mares 1986), and broad geographic distribution coincident with $S$. mansoni endemic areas, we suggest that these ro- dents must be regarded as influential factors in the maintenance of the schistosomiasis transmission, and therefore they should be taken into account in epidemiology surveys.

\section{ACKNOWLEDGMENTS}

To Dr W Lobato Paraense for providing the parasite strain used in this study. To Dr José Roberto Machado e Silva for valuable comments on the manuscript, and to Dr Pedro Hernán Cabello for contribuition in statistical analysis.

\section{REFERENCES}

Antunes CMF, Andrade RM, Katz N, Coelho PMZ, Pellegrino J 1973. Role of Nectomys squamipes in the epidemiology of Schistosoma mansoni infection. Ann Trop Med Parasit 67: 67-73.

Bastos OC, Silva AMA, Souza EP, Lemos-Neto RC, Piedrabuena AE 1982. Ocorrência de linhagens humana e silvestre de Schistosoma mansoni, na préamazônia. I - Estudo em moluscos. Rev Saúde Publ São Paulo 16: 292-298.

Bastos OC, Sadigurky M, Nascimento MDSB, Brazil RP, Holanda JC 1984. Holochilus brasiliensis nanus Thomas, 1897. Sugestão de modelo experimental para filariose, leishmaniose e esquistossomose. Rev Inst Med Trop São Paulo 26: 307-315.

Bonvicino CR 1994. Especiação do Rato d'Água Nectomys squamipes (Rodentia, Cricetidae): Abordagem Cariológica, Morfológica e Geográfica, $\mathrm{PhD}$ Thesis, Universidade Federal do Rio de Janeiro, Rio de Janeiro, $265 \mathrm{pp}$.

Carvalho DM 1982. Sobre a Importância do Nectomys squamipes na Epidemiologia da Esquistossomose Mansônica no Município de Sumidouro, R.J., MSc Thesis, Escola Nacional de Saúde Pública, Rio de Janeiro, $88 \mathrm{pp}$.

Cheever AW 1968. Conditions affecting the accuracy of potassium hydroxide digestion techniques for couting Schistosoma mansoni eggs in tissues. Bull Wld Helth Org 39 : 328-31.

Combes C 1990. Where do human schistosomes come from? Trends Ecol Evol 5: 334-337.

Coyne MJ, Smith G 1991. The regulation of mortality and fecundity in Schistosoma mattheei following a single experimental infection in sheep. Int J Parasitol 21: 877-882.

D'Andrea PS, Horta C, Cerqueira R, Rey L 1996. Breeding of the water rat (Nectomys squamipes) in the laboratory. Lab Animals 30: 369-376.

Dias LCS, Pires FA, Pinto ACW 1978. Parasitological and ecological aspects of schistosomiasis mansoni in the valley of Paraiba do Sul river (São Paulo, Brazil). 1. Natural infection of small mammals with Schistosoma mansoni. Trans $R$ Soc Trop Med Hyg 72: 496-500.

Ernest KA, Mares MA 1986. Ecology of Nectomys squamipes, the Neotropical Water rat, in central Brazil: home range, habitat selection, reproduction and behaviour. J Zool London 210: 599-612.

Imbert-Establet D, Moné H, Tchuenté LAT 1997. Permissiveness of two African wild rodents, Mastomys 
huberti and Arvicantis niloticus, to Schistosoma intercatatum: epidemiological consequences. Parasitol Res 83:569-573.

Katz N, Chaves A, Pellegrino J 1972. A simple device for quantitative stool thick-smear technique in schistosomiasis mansoni. Rev Inst Med Trop São Paulo 14: 397 - 400.

Machado-Silva JR, Galvão C, Presgrave OAF, Rey L, Gomes DC 1994. Host-induced morphological changes of Schistosoma mansoni Sambon, 1907 male worms. Mem. Inst Oswaldo Cruz 89: 411-416.

Maldonado Jr A, Lima MAD, Machado SCC, Machado EM, Machado-Silva JR, Rey L 1993. Infection of the rodent Nectomys squamipes with different loads of Schistosoma mansoni. Evaluation of the suitability between two copro-parasitological quantitative diagnostic techniques. Proceedings of the IV International Symposium on Schistosomiasis, Rio de Janeiro, RJ, Brazil.

Maldonado Jr A, Machado-Silva JR, Rodrigues-Silva R, Lenzi HL, Rey L. 1994. Evaluation of the resistance to Schistosoma mansoni infection in Nectomys squamipes (Rodentia: Cricetidae), a natural host of infection in Brazil. Rev Inst Med Trop São Paulo 36: 193-198.

Moné H 1997. Change in Schistosoma sex ratio under the influence of a biotic environmental-related factor. J Parasitol 83: 220-223.

Paraense WL, Corrêa L. 1989. A potencial vector of Schistosoma mansoni in Uruguay. Mem Inst Oswaldo Cruz 84: 281-288.

Pellegrino J, Faria J. 1965. Oograma method for screening of drug schistosomiasis mansoni. Amer J Trop Med Hyg 14: 363-369.

Pellegrino J, Siqueira AF. 1956. Técnica de perfusão para coleta de Schistosoma mansoni em cobais experi- mentalmente infectadas. Rev Bras Doenças Trop 8: 589-597.

Picot H 1992. Holochilus brasiliensis and Nectomys squamipes (Rodentia, Cricetidae) natural hosts of Schistosoma mansoni. Mem Inst Oswaldo Cruz 87 Suppl. IV: 255-260.

Rey L 1993. Non-humam vertebrate hosts of Schistosoma mansoni and schistosomiasis transmission in Brazil. Res Rev Parasit 53: 13-25.

Rodrigues-Silva R 1988. Nectomys squamipes e Akodon arviculoides (Rodentia: Cricetidae) como Hospedeiros Naturais do Schistosoma mansoni em Sumidouro (RJ - Brasil) - Emprego do Nectomys como Modelo Alternativo no Estudo da Esquistossomose Mansoni. Msc Thesis, Instituto Oswaldo Cruz, Rio de Janeiro, 147 pp.

Rodrigues-Silva R, Silva JRM, Faerstein NF, Lenzi HL, Rey L 1992. Natural infection of wild rodents by Schistosoma mansoni parasitological aspects. Mem Inst Oswaldo Cruz 87: 271-276.

Sène M, Duplantier JM, Marchand B, Hervé JP 1996. Susceptibility of rodents to infection with Schistosoma mansoni in Richard-Toll (Senegal). Parasite 4: 321-326.

Siegel S 1975. Estatística Não-paramétrica para as Ciências do Comportamento, Ed. McGraw-Hill, 350 pp.

Silva TM, Andrade ZA 1989. Infecção natural de roedores silvestres pelo Schistosoma mansoni. Mem Inst Oswaldo Cruz 84: 227-235.

Souza VAM, Rodrigues-Silva R, Maldonado Jr A, Machado-Silva JR, Rey L 1992. Nectomys squamipes (Rodentia - Cricetidae) as an experimental model for schistosomiasis mansoni. Mem Inst Oswaldo Cruz 87: 277-280. 
